\title{
A Review on Synthesis, Characterization Methods and Biological Activities of Semicarbazone, Thiosemi-Carbazone and Their Transition Metal Complexes
}

\author{
Fekadu Muleta* Tajeldin Alansi Rajalakshmanan Eswaramoorthy \\ Faculty of Applied Natural Science, Department of Applied Chemistry, Adama Science and Technology \\ University, Adama, Ethiopia
}

\begin{abstract}
Semicarbazones and thiosemicarbazones are compounds obtained by condensation of Semicarbazides and thiosemicarbazide with suitable aldehydes or ketones. They are potent intermediates for the synthesis of pharmaceutical and bioactive materials and thus, they are used extensively in the field of medicinal chemistry. The development of new beneficial bioactive compounds exhibiting different biological activities is one of the crucial aims in medicinal and bioinorganic chemistry. Semicarbazones, thiosemicarbazones and their derivatives have been evaluated as antibacterial, antifungal, antioxidant, antiviral, radical scavenging, antitubercular, antitumor and anticancer therapeutics especially when bind to transition metals. Their biological activities are considered to be related to their ability to form chelates with metals. The structures of the compounds have been characterized on the basis of their IR and $1 \mathrm{H}-\mathrm{NMR}$ data. Studies have been conducted on compounds bearing $-\mathrm{N}=\mathrm{N}-,-\mathrm{N}-\mathrm{C}=\mathrm{S}$, and $-\mathrm{CH}=\mathrm{N}$ - as pharmacophore. Accordingly by considering this biological potential herein, the synthesis root of some of these derivatives and complexes are reviewed as for biological activities and is aim to organize the different biological activities of some synthesized semicarbazone and thiosemicarbazone derivatives with transition metals. Keywords: Semicarbazone, thiosemicarbazones, Metal Complexes, antibacterial, antifungal and anticancer therapeutics.
\end{abstract}

DOI: $10.7176 / \mathrm{JNSR} / 9-17-04$

Publication date:September $30^{\text {th }} 2019$

\section{INTRODUCTION}

Semicarbazones and thiosemicarbazones are important compounds obtained by condensation of Semicarbazides with suitable aldehydes or ketones. Thiosemicarbazone is a derivative of semicarbazone which contain sulfur atom in place of oxygen. The semicarbazones and thiosemicarbazones usually behave as chelating ligands and usually react with metallic cations giving complexes. The synthesis of transition metal complexes with semicarbazones and thiosemicarbazone ligands are important due to their pharmacological properties ${ }^{1}$. After the discovery of the chemotherapeutically active platinum complexes of thiosemicarbazide derivatives, most of the thiosemicarbazone compounds showing biological activities were synthesized ${ }^{2}$. Semicarbazone and thiosemicarbazone ligands usually coordinate to transition metals usually through their oxygen, nitrogen, and sulphur donor atoms in their $(\mathrm{N}, \mathrm{S})$ bidentate form or $(\mathrm{N}, \mathrm{N}, \mathrm{S}$ or $\mathrm{O}, \mathrm{N}, \mathrm{S})$ tridentate form, to form metallic complexes ${ }^{3,4}$. The synthesis, spectral and antifungal studies of the bidentate ligands with the $\mathrm{Ni}(\mathrm{II}), \mathrm{Pd}(\mathrm{II})$ and $\mathrm{Pt}(\mathrm{II})$ metal ions were reported ${ }^{5}$. Semicarbazones and thiosemicarbazones have a considerable interest in the field of chemistry and biology due to their antibacterial, antifungal ${ }^{6}$, antimalarial and antiviral ${ }^{7}$ activities through binding to metals in cells ${ }^{8}$. Usually they behave as chelating ligands containing donor imines groups which react with transition metal vacant d-orbital giving complexes. The complexes can exhibit bioactivities which are not shown by the free ligands ${ }^{9}$.

Accordingly by considering the biological potential of semicarbazone, thiosemicarbazone and their derivatives of transition metal complexes, herein, the synthesis root of some of these derivatives is reviewed for antibacterial, antifungal, antimalarial, antineoplastic and antiviral activities and having sound scope in research and developing process in pharmaceutical and medicinal chemistry for biological system.

\section{ROLES OF COMMON TRANSITION METALS IN BIOLOGICAL SYSTEM}

The biological properties of semicarbazones and thiosemicarbazones are often related to metal ion coordination. Firstly, lipophilicity, which controls the rate of entry into the cell, is modified by coordination ${ }^{10}$. Moreover, coordination may lead to significant reduction of drug-resistance ${ }^{11}$. The semicarbazone and thiosemicarbazone usually behave as chelating ligands and usually react with metallic cations giving complexes. They are versatile ligands in both neutral and anionic forms. Here is some of the chemistry of common transition metals that can bind with semicarbazone and thiosemicarbazone ligands to act as bioactive molecule.

Nickel: - In biological systems nickel can act as active sites of certain hydrogenases and dehydrogenases enzymes ${ }^{12}$. Nickel centers such as at the active sites of certain ureases, methyl Scoenzyme-M-methyl reductase, hydrogenases and play an active role in mutagenicity of nickel compounds ${ }^{12}$. Labile four coordinated Ni(II) complexes with tridentate thiosemicarbazone and semicarbazone ligands shows antibacterial activities, where as six coordinated 
$\mathrm{Ni}$ (II) complexes with thiosemicarbazone and semicarbazone ligands exhibit biological activity against the microorganism test ${ }^{13}$. Also nickel (II) complexes with octadiensemicarbazones have strong inhibitory activity against Staphylococcus aureus and Eschericia Coli ${ }^{14}$.

Zinc: - is one of the essential trace elements, found in high concentration in the human red blood cells ${ }^{15}$. It is the second most abundant trace metal in human body and present to the average of $2.3 \mathrm{~g}$ in the adult human body ${ }^{16}$. Zinc(II) is a symmetrical $\left(\mathrm{d}^{10}\right)$, borderline and interacts strongly with $\mathrm{O}, \mathrm{N}$ and $\mathrm{S}$ donor ligands ${ }^{17}$. Zink is the essential cofactor for the observed biological functions (most associated with protein and enzymes). In human body it can either participate directly in chemical catalysis (zink enzyme) or be important for maintaining protein structure and stability ${ }^{18}$

Zink required for the activities of $>300$ enzymes, covering all six classes of enzymes (as catalytic, co-catalytic and structural site) ${ }^{19}$ :

$\begin{array}{lll}\square & \text { oxidoreductases } & \text { - lyases } \\ \square & \text { Transferases } & \text { - isomerases } \\ \square & \text { Hydrolyases } & \text { - ligases }\end{array}$

Tetrahedral and octahedral $\mathrm{Zn}(\mathrm{II})$ complexes of thiosemicarbazide and thiosemicarbazone of bidentate ligands was reported ${ }^{20}$. Ligands, such as ethylacetoacetatesemicarbazone and thiosemicarbazone acting as tridentate in zinc complexes, in which the third coordinating center is provided by the carbonyl group ${ }^{21}$.

Cadmium: - Cadmium containing ores are very rarely found and thus to occur in small quantities ${ }^{22}$. Cadmium forms complexes by chelating with nitrogen donor ligands like semicarbazone and thiosemicarbazone compounds $^{23}$. The most stable $\mathrm{Cd}(\mathrm{II})$ complexes forms with soft donor atoms $(\mathrm{S}>>\mathrm{N}>\mathrm{O})$. The stability of the complexes increases with the increase in number of coordination groups contributed by the semicarbazone and thiosemicarbazone derivative ligands ${ }^{24}$.

Copper: - Copper is a first-row transition metal which is essential for life and is present in almost all living organisms ${ }^{25}$. Copper catalyses redox reactions are used in biological systems primarily in the reduction of oxygen to water ${ }^{26}$. Due to the presence of unpaired electrons, all the copper (II) complexes are paramagnetic in nature. More interest in Schiff base compounds containing thiosemicarbazone and their transition metal complexes have improved in the area of chemistry and biology due to biological activity ${ }^{27}$. Metal complexes containing $\mathrm{Cu}(\mathrm{II}) \mathrm{and}$ iron(II) are more active than the uncoordinated semicarbazone and thiosemicarbazone and this increase in biological activity ${ }^{28}$.

Cobalt: -The most common ligand type used to stabilize the cobalt(III) ion in aqueous solution is the chelating $\mathrm{N}, \mathrm{O}$ donor ligand. Cobalt(III) complexes derived from this ligand donor set have found application as antibacterial or antiviral agents. One of the most promising classes of Co(III) complexes containing N, O donor ligands is the Cobalt(III) complexes series ${ }^{29}$. Oxygen activators ${ }^{30}$, dioxygen carriers and also in enantioselective reduction. It also forms complexes with semicarbazone which act as bioactive compounds ${ }^{31}$.

Manganese: - is important for normal physiological functioning in humans and animals. It act as an active sites for metalloprotiens. In metalloprotiens, it can exist in any of the five oxidation states or in mixed valence states ${ }^{32}$. In photosystem II it is found astetranuclear manganese comple ${ }^{33}$. Manganese coordination compounds have improving as homogeneous catalysts in oxidation reactions. Manganese has an important role in many enzymatic systems such as peroxidase, peroxide dimutase, dioxygenase in which mononuclear manganese active sites are $\operatorname{seen}^{34}$. Metal complexes of Manganese have an important role in bioinorganic chemistry ${ }^{35}$. The chemistry of manganese in various oxidation states in various combinations of nitrogen and oxygen donor ligands like semicarbazone and thiosemicarbazone is currently witnessing intense biological activity ${ }^{36}$.

\section{CHEMICAL BONDING NATURE OF SEMICARBAZONES AND THIOSEMI-CARBAZONE WITH TRANSITION METALS}

The raw material for the synthesis of semicarbazone and thiosemicarbazone is semicarbazides, the compound prepared by treating urea with hydrazine $\mathrm{as}^{37}$ :

\section{Structures}

$$
\mathrm{OC}\left(\mathrm{NH}_{2}\right)_{2}+\mathrm{N}_{2} \mathrm{H}_{4} \rightarrow \mathrm{OC}\left(\mathrm{NH}_{2}\right)\left(\mathrm{N}_{2} \mathrm{H}_{3}\right)+\mathrm{NH}_{3}
$$<smiles>NC(N)=O</smiles>

Urea<smiles>NN</smiles>

hydrazine<smiles>CNNC(N)=O</smiles>

Semicarbazides<smiles>NNC(N)=S</smiles>

Thiosemicarbazide

Semicarbazone/ thiosemicarbazone are a derivative of an aldehyde or ketone formed by a condensation reaction between a ketone or aldehydes and semicarbazide/thiosemicarbazide. As shown in scheme (3.1) bellow. 


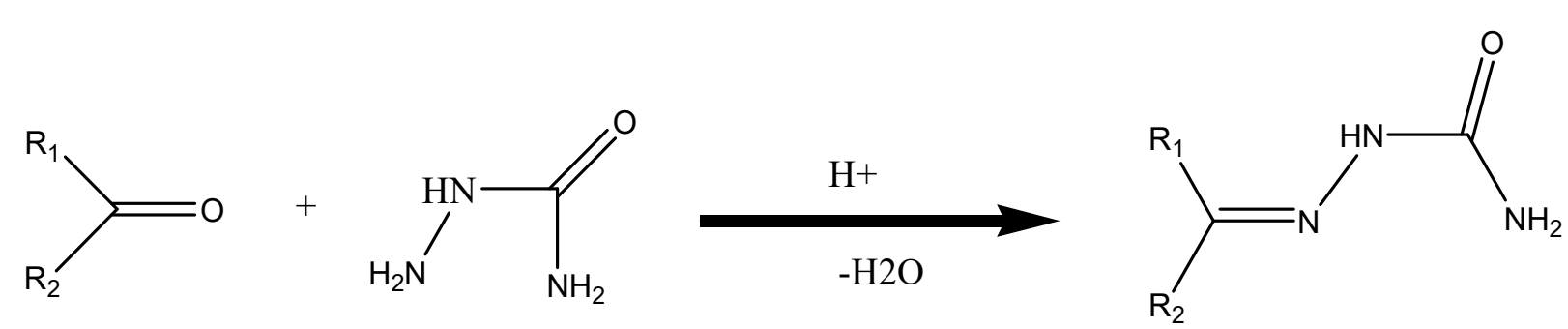

Scheme -3.1:- synthesis root of Semicarbazone

A review of semicarbazone and thiosemicarbazone showed that in free unsubstituted semicarbazones in the solid state, the $\mathrm{C}=\mathrm{N}-\mathrm{NH}-\mathrm{CO}-\mathrm{NH}_{2}$ backbone is usually planar, with $\mathrm{O}$ atom trans to azomethine $\mathrm{N}$ atom ${ }^{38}$.<smiles>[R2]C([R7])=NNC(N)=O</smiles><smiles>[R2]C([R])=NN([R3])C(=S)N([R4])[R4]</smiles>

Fig.3.1:- General Structure of semicarbazone \& Thiosemicarbazones

\section{Schiff Base}

A Schiff Base, named after Hugo Schiff, is a compound with a functional group that contains a carbon-nitrogen double bond with the nitrogen atom connected to an aryl or alkyl group, not hydrogen ${ }^{39}$ (Figure 3.2). Schiff bases in a broad sense have the general formula $\mathrm{R}_{1} \mathrm{R}_{2} \mathrm{C}=\mathrm{NR}_{3}$, where $\mathrm{R}$ is an organic side chain. In this definition, Schiff base is synonymous with azomethine(Figure 3.3). Some restrict the term to the secondary aldimines (azomethines where the carbon is connected to a hydrogen atom), thus with general formula $\mathrm{RCH}=\mathrm{NR}{ }^{40}$.

The chain of the nitrogen makes the Schiff base a stable imine. A Schiff base derived from aniline, where $\mathrm{R}_{3}$ is a phenyl or a substituted phenyl, can be called an anil ${ }^{41}$.<smiles>[R]N=C[2H]</smiles>

Fig.3.2:- General Structure of a Schiff Base<smiles>[R2]C([R2])=Nc1ccccc1</smiles>

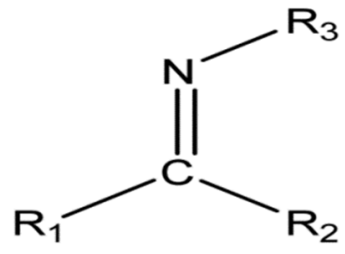

Fig.3.3:- General Structure of an azomethine

Fig.3.4:- General Structure of an anil

Interestingly, semicarbazone and thiosemicarbazone are the Schiff bases, showing a variety of coordination modes with transition metals, the coordination mode is influenced by the number and type of substituent ${ }^{42}$. That is due to the active donor sites of ligand vary depending upon the substituent. According to the reports ${ }^{43}$ the coordination mode of semicarbazone is very sensitive towards minor variation in the experimental conditions. They are very versatile ligands which can coordinate to metal as neutral molecules or after deprotonation as anionic ligands and can adopt a variety of different coordination modes.

Thiosemicarbazones and semicarbazones act as ligands because;-

i. They have better co-ordination tendency.

ii. They form more stable complexes.

iii. They have better selectivity.

iv. They may form macrocyclic ligands

They have the ability to produce some new and unique complexes with enhanced biological activities ${ }^{44}$. An interesting attribute of semicarbazone is that in solid state, they predominately exist in the keto form, whereas in solution state, they exhibit a keto-enol tautomerism ${ }^{45}$. Keto form act as neutral bidentate ligand and the enol form 
can deprotonate and serve as mono -anionic bidentate ligand in metal complexes. Thus semicarbazone are versatile ligands in both neutral and anionic forms as shown in scheme -3.2 bellow.<smiles>[R]NC(=O)NN=C([R])[R]</smiles>

Keto<smiles>[R]NC(O)=NN=C([R])[R]</smiles>

Enol

Scheme-3.2:- keton-enol tautomerism of semicarbazones

Both tautomeric forms have an efficient electron delocalization along the semicarbazone moiety. Aromatic substituent on semicarbazone skeleton can furher enhances the delocalization of electron charge density. These classes of compounds usually react with metallic cations giving complexes in which the semicarbazone behave as chelating ligands upon coordination to a metal centre; the delocalization is further increased through the metal chelate rings. The coordination possibilities are further increased if the substituent has additional donor atoms. In most of the complexes semicarbazone were synthesized as tridentate ligand and in some cases semicarbazone exhibit as potential quadridentate when the second pyridyl nitrogen involved in coordination process ${ }^{46}$.

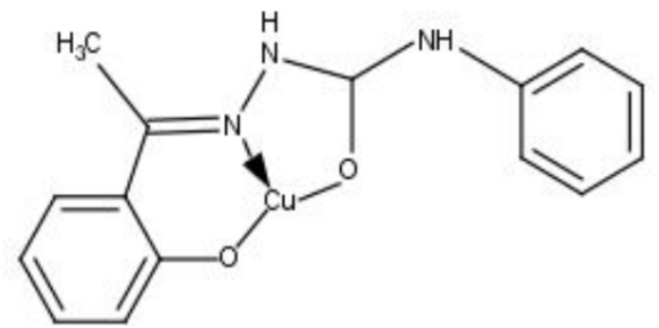

$\mathrm{O}, \mathrm{N}, \mathrm{O}$-tricoordination

The different coordination modes of substituted benzaldehyde semicarbazone given as;

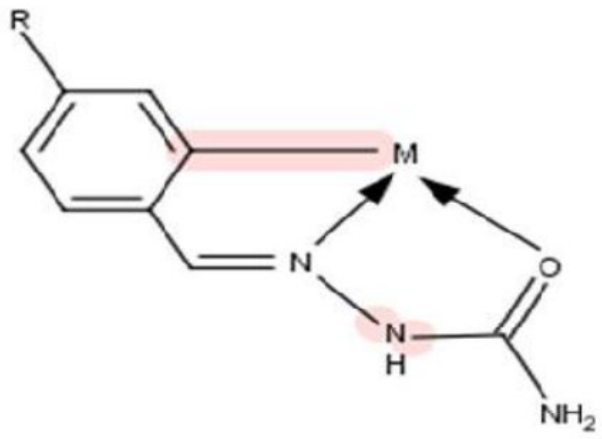

C, N, O-tricoordination

$\mathrm{N}, \mathrm{O}$-coordination forming five membered chelate

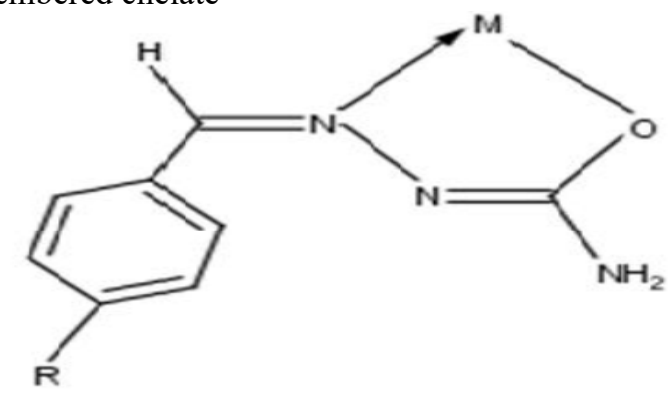

An unusual four member chelate formation N, O-donor 


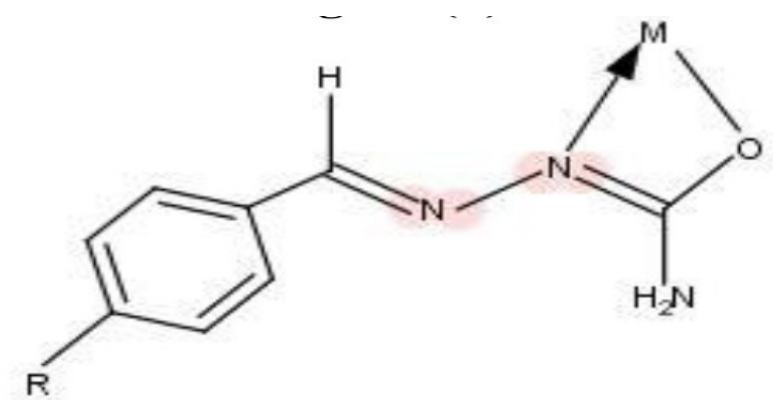

Schemes - 3.3:- Different coordination modes of semicarbazone

Owing the availability of $\mathrm{NH}-\mathrm{C}=\mathrm{S}$ group, thiosemicarbazone exhibit thione - thiol tautomerism. In solid they exist in thione form but in solution they exist as an equilibrium mixture of thione and thiol form ${ }^{47}$ as shown in the Scheme- 3.4.

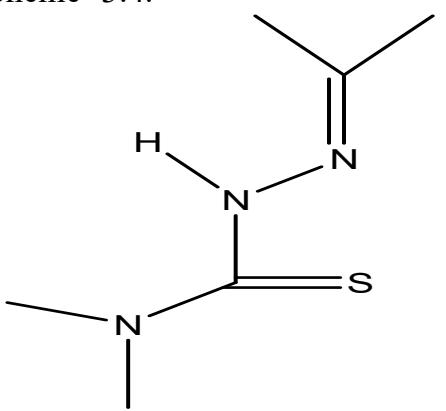

Thione

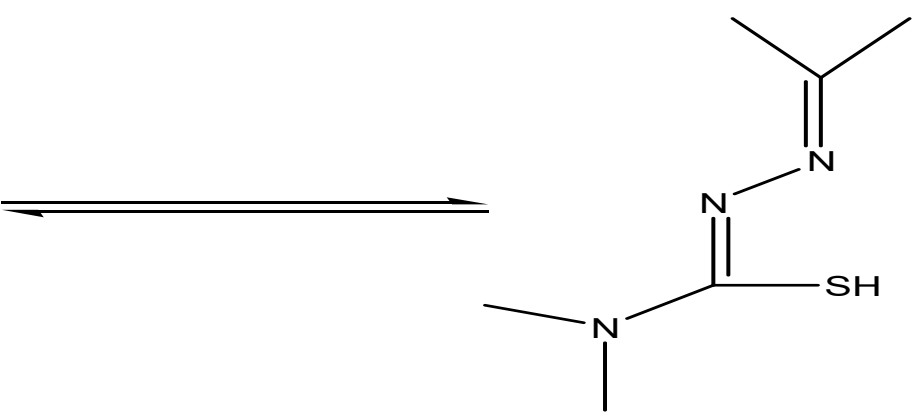

Thiol

Scheme-3.4:- Equilibrium mixture of thione and thiol

Thiosemicarbazone can adopt a variety of different coordination modes. In most of the series, thiosemicarbazone coordinate as bidentate ligands via azomethine nitrogen and thione/thiolato sulphur.

SYNTHESIZED COMPOUNDS OF SOME SEMICARBAZONE, THIOSEMI-CARBAZONE AND DERIVATIVES OF THEIR TRANSITION METAL COMPLEXES

Copper (II) Complexes of Schiff Base Ligand Derived From

3-Methoxysalicylaldehyde with Semicarbazide and Thiosemicarbazide

$\checkmark$ Synthesis of Schiff base ligands $\mathbf{L}_{\mathbf{1}}, \mathbf{L}_{\mathbf{2}}$ and $\mathbf{L}_{\mathbf{3}}{ }^{48}$.

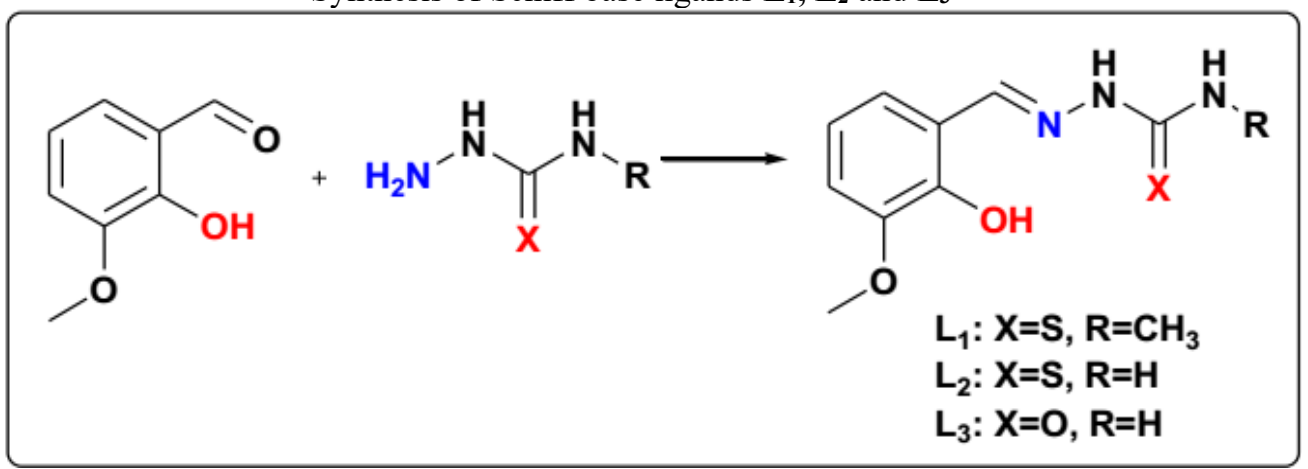

Scheme - 3.5:- Synthesis of Schiff base ligands $L_{1}, L_{2}$ and $L_{3}$ 


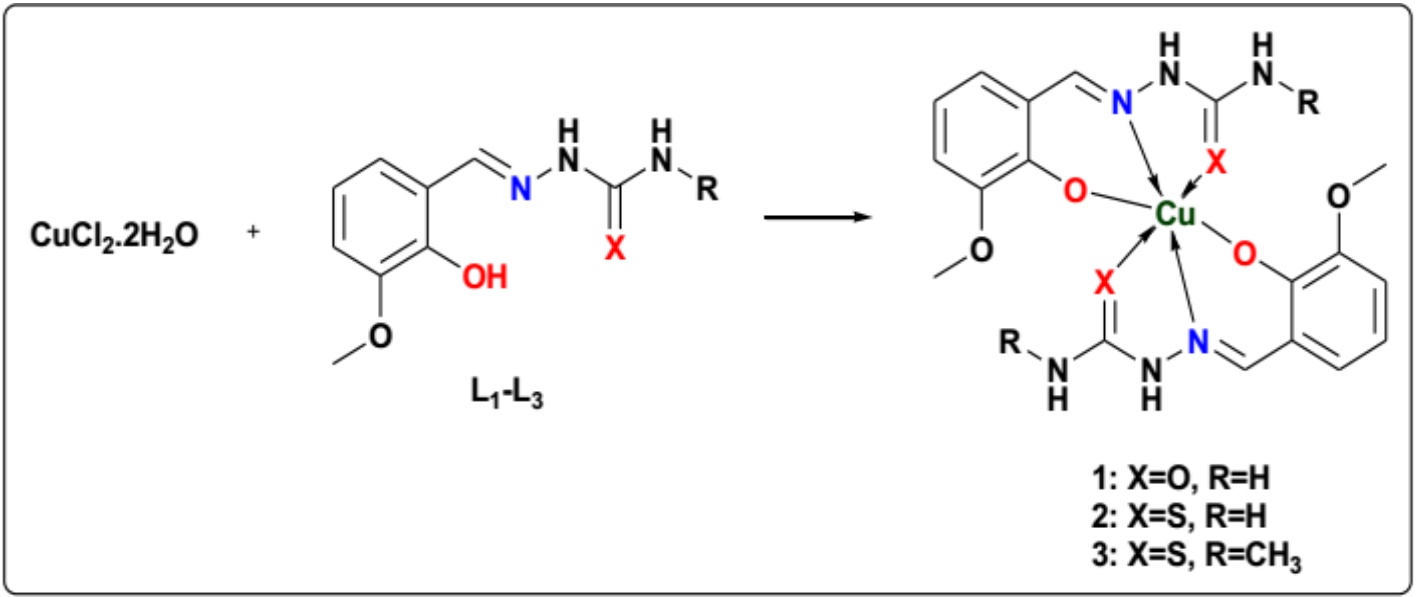

Scheme -3.6:- Synthesis of copper (II) complex of 1, 2 and 3

\section{Anti-microbial screening}

The anti-microbial activity of synthesized ligands $\mathbf{L}_{\mathbf{1}}-\mathbf{L}_{\mathbf{3}}$ and their copper (II) complexes were reviewed ${ }^{49}$.<smiles>CNC(=S)N/N=C/c1cccc(OC)c1O</smiles>

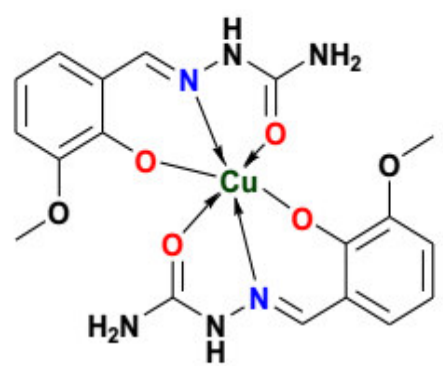

1<smiles>CNC(=S)N/N=C/c1cccc(OC)c1OC</smiles>

1 a

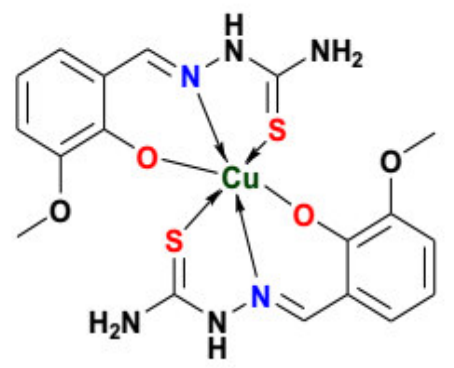

2<smiles>CNC(=S)N/N=C/c1cccc(OC)c1OC</smiles>

$1 b$

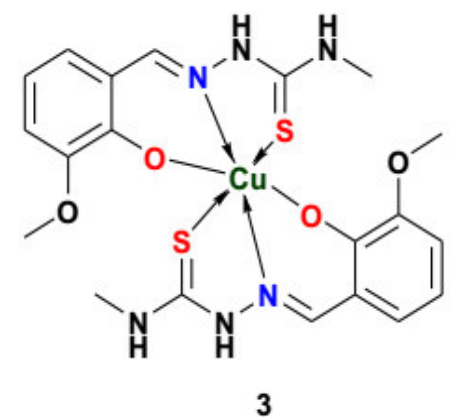

Scheme - 3.7:- Structure of Schiff base ligand $\mathrm{L}_{1}-\mathrm{L}_{3}$ and their copper (II) complexes 
<smiles>CNC(=S)N/N=C/c1cccc(OC)c1O</smiles>

$\mathrm{L}_{1}$<smiles>CNC1=[SH][Ge](Cl)(Cl)Oc2c(cccc2OC)C=N1</smiles>

1a<smiles>CNC1=[SH][Ge](Br)(Br)Oc2c(cccc2OC)/C=N/1</smiles>

1b<smiles>COc1cccc(/C=N/NC(N)=S)c1O</smiles><smiles>COc1cccc(/C=N/NC(N)=O)c1O</smiles>

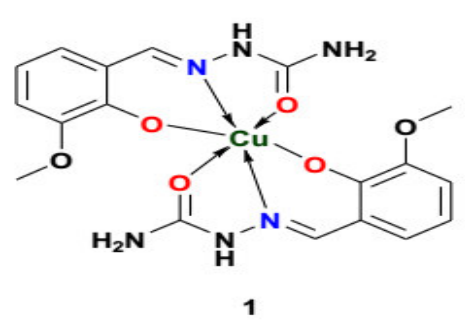

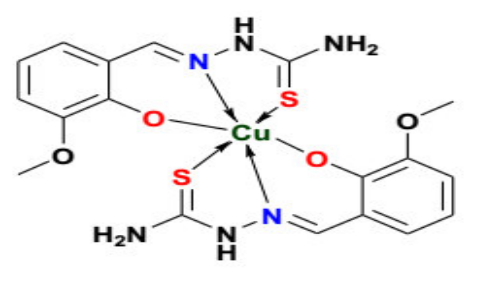

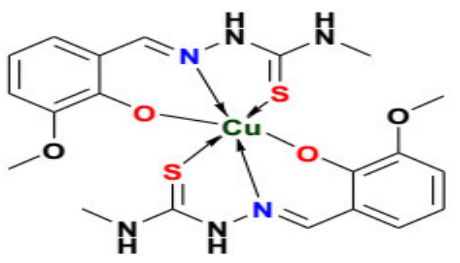

Scheme -3.8:- Structure of Schiff base ligand $\mathrm{L}_{1}-\mathrm{L}_{3}$ and their copper (II) complex (1a-b and 1-3)

The entire complexes have remarkable microbial activity against bacteria and fungi. From the reviews results it shows that the copper (II) complexes 1-3 are found to have microbial activity than the parent ligands (Fig.3.5 and Fig.3.6) ${ }^{49}$.

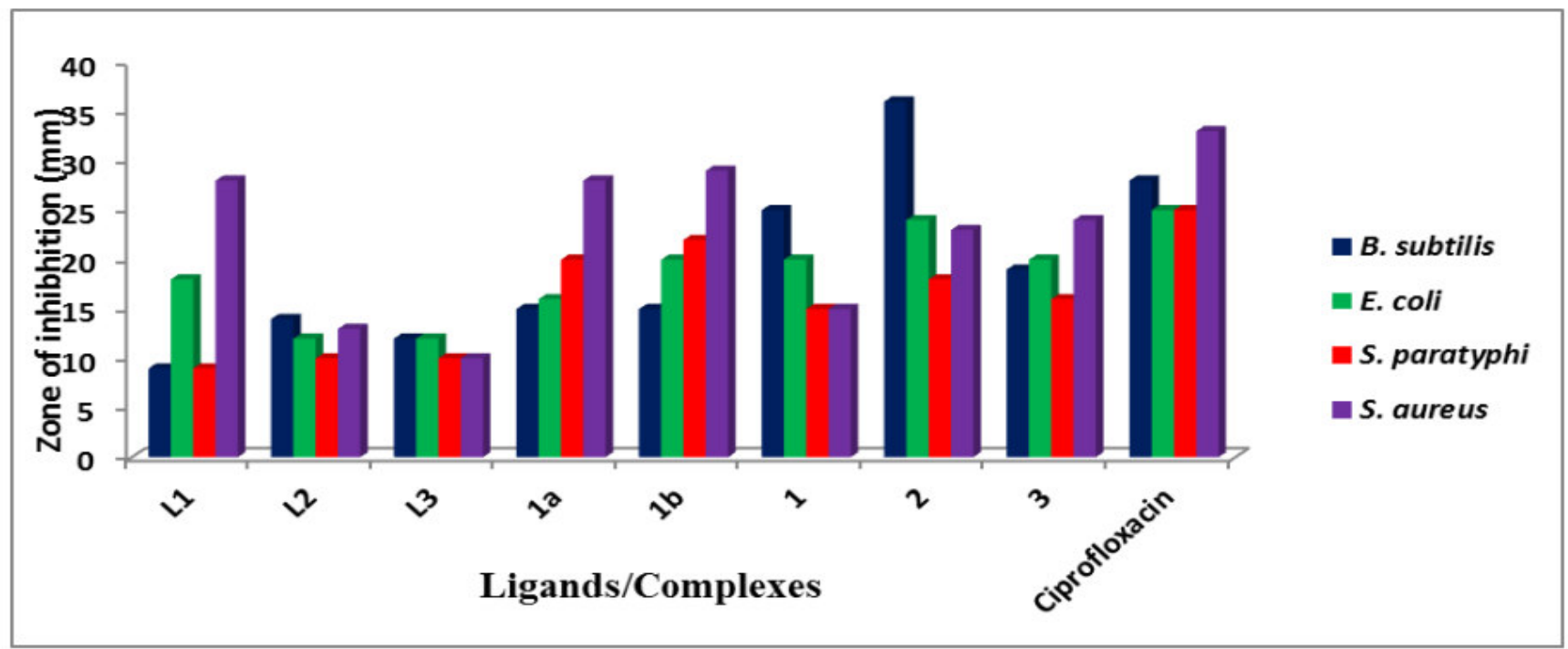

Fig.3.5:- Antibacterial activity of Schiff bases and their copper (II) complexes. 


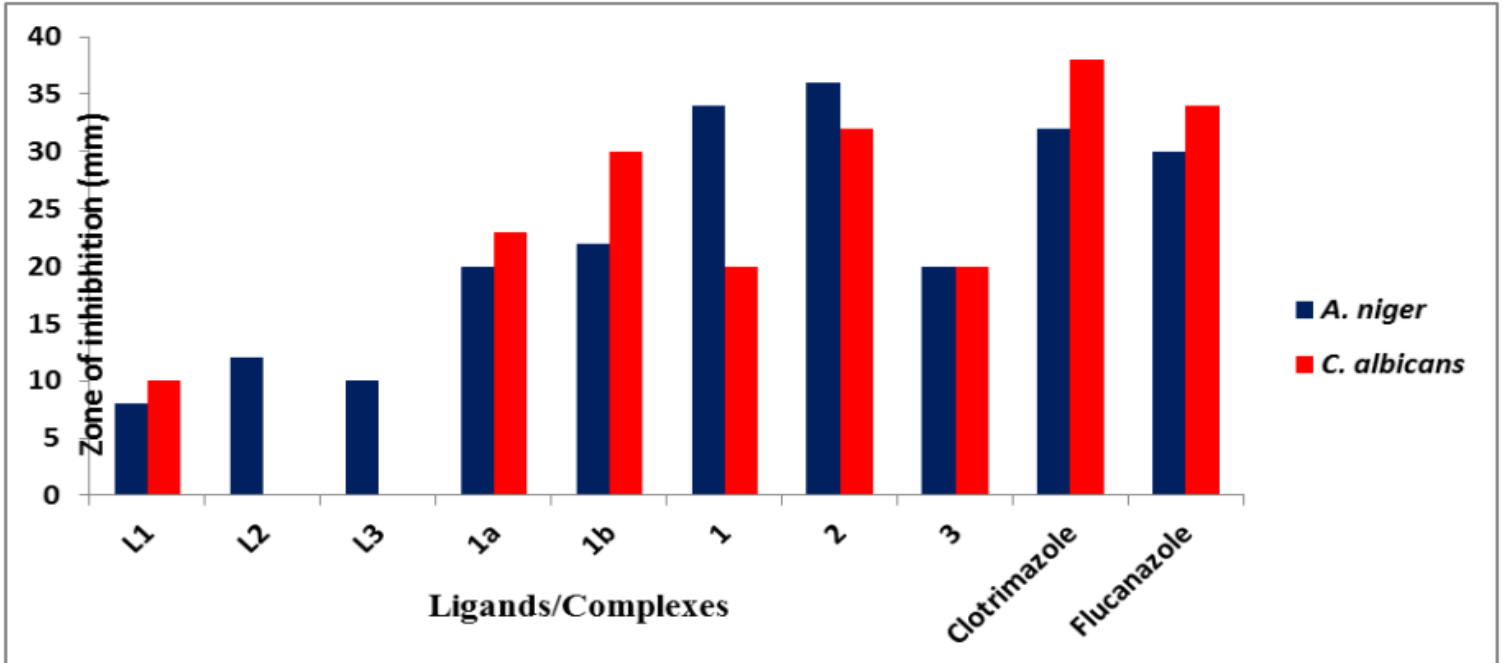

Fig.3.6:- Antifungal activity of Schiff bases and their copper (II) complexes

Lapachol and its thiosemicarbazone and semicarbazone derivatives

Lapachol is chemically modified to obtain its thiosemicarbazone and semicarbazone derivatives as shown in Scheme 3.950.

A<smiles>CC(C)=CCC1=C(O)C(=O)c2ccccc2C1=O</smiles>

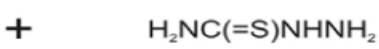

Lapachol

B<smiles>CC(C)=CCC1=C(O)C(=O)c2ccccc2C1=O</smiles>

Lapachol

C<smiles>CC(C)=CCC1=C(O)C(=O)c2ccccc2C1=O</smiles>

$+$

$\mathrm{H}_{2} \mathrm{NC}(-\mathrm{O}) \mathrm{NHNH}_{2}$

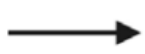

Semicarbazone

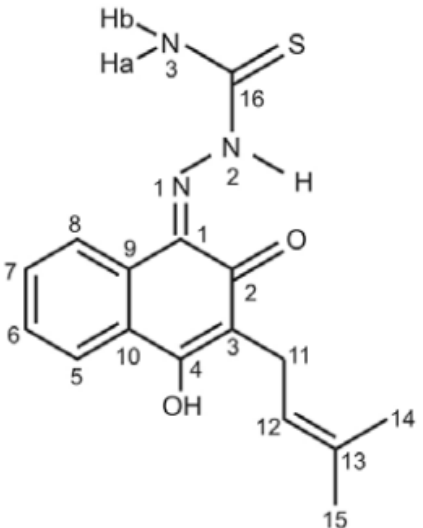<smiles>[2H]N(N=C1C(=O)C(CC=C(C)C)=C(O)c2ccccc21)C(=S)N([2H])c1ccccc1</smiles>

Thiosemicarbazone<smiles>[2H]N([2H])C(=O)N/N=C1\C(=O)C(CC=C(C)C)=C(O)c2ccccc21</smiles><smiles>CC(C)=CCC1=C(C)c2ccccc2C(=NN(C)C(=O)N(C)c2ccccc2)C1=O</smiles>

Scheme -3.9:- preparation of lapachol thiosemicarbazone and semicarbazone and structures 


\section{Biological activity}

The thiosemicarbazone and semicarbazone derivatives of lapachol exhibited antimicrobial activity against the bacteria Enterococcus faecalis and Staphylococcus ${ }^{51}$.

\section{Benzaldehyde Thiosemicarbazone Derivatives}

The Pd complex of benzaldehyde thiosemicarbazone as shown in (Scheme -10) is toxic for host cell of microorganism and can act as antiviral and antibacterial activities as reported ${ }^{52,52}$.<smiles>[R]c1ccccc1/C=N/NC(N)=S</smiles>
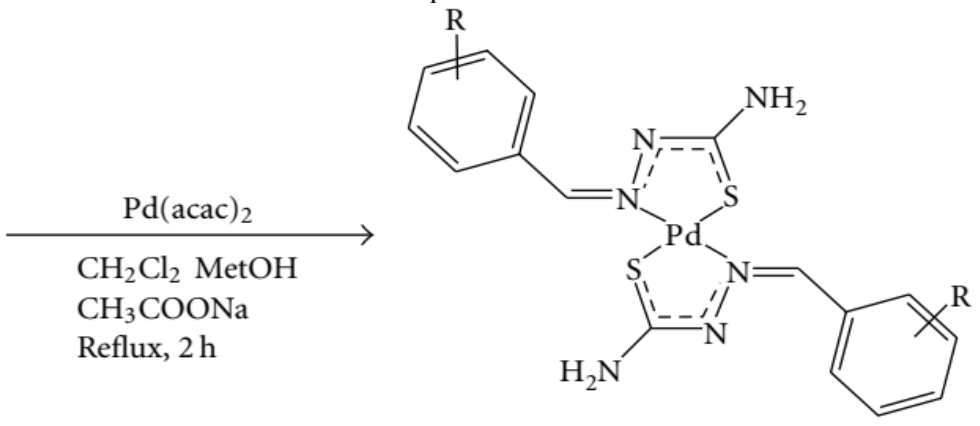

$\operatorname{Pd}\left(\mathrm{L}^{1}\right)_{2}(\mathrm{R}=\mathrm{H})$

$\mathrm{Pd}\left(\mathrm{L}^{2}\right)_{2}(\mathrm{R}=m-\mathrm{CN})$

$\mathrm{Pd}\left(\mathrm{L}^{3}\right)_{2}\left(\mathrm{R}=o-\mathrm{NO}_{2}\right)$

Scheme -10: Synthesis of the palladium (II) bis-chelate complexes

\section{CHARACTERIZATION OF THE COMPLEXES OF SEMICARBAZONE AND THIOSEMICARBAZONE}

Several methods, conventional and modern are available for elucidating the structure of ligands and their coordination compounds. The complexes are characterized by elemental analysis, molar conductance, magnetic susceptibility measurement and spectral (electronic, IR, EPR, 1HNMR).

\section{A. Elemental analysis}

The $\mathrm{C}, \mathrm{H}$ and $\mathrm{N}$ can be analyzed on elemental analyzer. The nitrogen content of the complexes was determined using kjeldahl, method ${ }^{53}$.

\section{B. Magnetic Susceptibility measurement}

The magnetic susceptibility and the magnetic moment are often used to describe the magnetic behavior of substance. A magnetic dipole is a macroscopic or microscopic magnetic system in which the north and south poles are separated by a short but definite distance. In the presence of a magnetic field, magnetic dipoles within a material experience a turning effect and become partially oriented. The magnetic moment refers to the turning effect produced when

magnetic is placed in a magnetic field. The fundamental unit of magnetic moment is the Bohr magneto. For isotropic the magnetic susceptibility $(\mathbf{x})$ is defined by,

$$
\mathbf{X}=\mathbf{M} / \mathbf{H}
$$

Where $\mathrm{M}$ is the magnetic moment per unit volume (magnetization) and $\mathrm{H}$ is the strength of magnetic field. The molar susceptibility $\mathbf{M}$ is simply defined as the susceptibility per gram mole.

Hence, $\mathbf{X}_{\mathbf{M}}=\mathbf{X x}$ molecular weight

The magnetic susceptibility value calculated from magnetic measurement is the sum of paramagnetic and diamagnetic susceptibility. To calculate the exact $\left(\mu_{\mathrm{eff}}\right)$, the value of diamagnetic susceptibility is subtracted from the susceptibility calculated from observed results. When the structural formula of the complexes is correctly known, diamagnetic correction can be calculated from Pascal, constant.

\section{Infrared spectroscopy}

The vibrational states of a molecule can be probed in a variety of ways. The most direct way is infra-red spectroscopy because of vibrational transition typically require an amount of energy that corresponds to infrared region of the spectrum 4000 and $400 \mathrm{~cm}-1$ (wave number) ${ }^{54}$.

Radiation in this region can be utilized in structural determination in coordination chemistry by making use of the fact that interatomic bonds in ligand absorb it.

\section{Electronic spectroscopic}

Electronic spectroscopy is the measurement of the wavelength and intensity of absorption of near ultra violet and visible light by a sample. UV- vis spectroscopy is usually applied to organic molecule and inorganic ions or complexes. The absorption of UV or visible radiation corresponds to the excitation of outer electrons. There are three types of electronic transition that can be considered for coordination compounds. Many inorganic species 
show ligand to metal charge transfer. Charge transfer (LMCT) transition and metal to ligand charge transfer (MLCT) transition (not as common as (LMCT). Transition probability in ligand field transition (d-d transition) can be determined by the spin selection rule and the orbital (Laporte) selection rule ${ }^{55}$.

\section{BIOLOGICAL ACTIVITIES OF SEMICARBAZONES, THIOSEMICARBAZONES AND THEIR METAL COMPLEXES}

Semicarbazones present a wide range of bioactivities, and their chemistry and pharmacological applications have been extensively investigated. The biological properties of semicarbazones are often related to metal ion coordination. Firstly, lipophilicity, which controls the rate of entry into the cell, is modified by coordination ${ }^{56}$. Also, the metal complex can be more active than the free ligand ${ }^{57}$. The mechanism of action can involve binding to a metal in vivo or the metal complex may be a vehicle for activation of the ligand as the cytotoxic agent. Moreover, coordination may lead to significant reduction of drug-resistance ${ }^{58}$. The semicarbazone and thiosemicarbazone usually behave as chelating ligands and usually react with metallic cations giving complexes. Some complexes with semicarbazones and thiosemicarbazones have received much attention due to their wide range of applications with as an antiviral, antibacterial ${ }^{59}$ and antimicrobial, antifungal activities ${ }^{60}$.

\section{Semicarbazones as Anti-Protozoa Agents}

A variety of 5-nitrofuryl semicarbazone (nitrofurazone) derivatives have been developed for the therapy of Chagas 'disease, a major problem in Central and South America. Chagas disease or American trypanosomiasis is produced by several strains of the protozoan parasite, Trypanosoma cruzi, which is transmitted to humans by blood-sucking bugs (Triatoma infest and Triatoma rubroviaria) ${ }^{61}$. Substituent with different electronic and steric properties has been introduced on $N^{4}$ of the nitrofurazone moiety ${ }^{61}$. The compounds were tested in vitro against $T$. cruzi epimastigote and in vivo in mice infected with the parasite ${ }^{61,62}$.

\section{As antibacterial and antifungal activity}

Thiosemicarbazones and their metal complexes present wide anti-microbial activity ${ }^{63}$. The antibacterial activity of a variety of 2-acetylpyridine thiosemicarbazones was determined in clinical isolates of bacteria. The compounds tested were reported that capable to inhibit Neisseria gonorrhoeae, Neisseria meningitides, Staphylococcus faecalis, Streptococcus faecalis and D Enterococcus ${ }^{64}$. Pt (II) complexes of 2-acetylpiridine thiosemicarbazone also showed a similar behavior, i.e. werelethal to gram-positive but inactive against gram-negative bacteria. The complexes were active against yeast ${ }^{65}$. In addition, a series of 2-(alpha-hydroxyacetyl) pyridine thiosemicarbazones exhibited potent inhibitory activity against penicillin-sensitive as well as penicillin-resistant $N$. gonorrhoeae, against $N$. meningitides, and Staphylococcus aureus. These new agents appeared to be less toxic to the host than the corresponding 2-acetylpyridine thiosemicarbazones ${ }^{66}$. The antimicrobial activities of 4 - and 6-coordinate $\mathrm{Ni}$ (II) complexes of thiosemicarbazones derived from 2- acetylpyridine and 2,6-diacetylpyridine were reported ${ }^{67}$. Only the labile complexes exhibited activity against Bacillus subtilis and S. aureus, suggesting that activity would correlate with ligand-replacement abilities ${ }^{68}$. Semicarbazone and thiosemicarbazones derived from 2- acetylpyridine, 2-furfuraldehyde, 2-acetylnaphtalene, 2- acetylthiophene, 2-acetylfuran and their corresponding $\mathrm{Mn}(\mathrm{II})$ complexes were tested on fungi (Macrophomina phaseolina, Fusarium oxysporum) and bacteria (Xanthomonas sp., E. coli and $S$. aureus) ${ }^{69,70}$. The complexes were more active than the free ligands, probably due to increased lipophilicity. Moreover, the thiosemicarbazones' complexes were more active than the semicarbazone analogues.

It was proposed that the ultimate action of structurally non-specific toxicants is the denaturation of cell proteins. Chelating agents are often powerful inhibitors of metalloenzymes so that the ligands may act by inhibiting the enzymes whose activity depends on metals ${ }^{71}$. Metallocene derivatives of titanium and zirconium with thiosemicarbazones derives were more active against the organisms than the ligands ${ }^{72}$. Many other thiosemicarbazones and metal complexes were screened for antibacterial and antifungal activity and 2formylpyridine thiosemicarbazones and their oxovanadium(IV) complexes exhibited powerful in vitro antibacterial activities towards $E$. coli ${ }^{73}$, and aryl thiosemicarbazones showed good activity against Aeromonas hydrophilia and Salmonella typhimurium ${ }^{74}$.

\section{THERMODYNAMIC AND KINETIC STABILITY OF SEMICARBAZONE AND THIOSEMICARBAZONE WITH THEIR TRANSITION METAL COMPLEXES}

The thermodynamic stability of metal ions with semicarbazone and thiosemicarbazone are denoted by stepwise formation constants as shown in equations bellow as (charges omitted for simplicity) ${ }^{75}$. 


$$
\begin{array}{crl}
\mathrm{M}+\mathrm{L} \Leftrightarrow \mathrm{ML} & K_{1}=\frac{[\mathrm{ML}]}{[\mathrm{M}][\mathrm{L}]} \\
\mathrm{ML}+\mathrm{L} \Leftrightarrow \mathrm{ML}_{2} & K_{2}=\frac{[\mathrm{ML} 2]}{[\mathrm{ML}][\mathrm{L}]} \\
\mathrm{ML}_{2}+\mathrm{L} \Leftrightarrow \mathrm{ML}_{3} & K_{3}=\frac{\left[\mathrm{ML}_{3}\right]}{\left[\mathrm{ML}_{2}\right][\mathrm{L}]}
\end{array}
$$

Overall stability constants as:-

$$
\begin{array}{cc}
\mathbf{M}+\mathbf{L} \Leftrightarrow \mathbf{M L} & \boldsymbol{\beta}_{1}=\frac{[\mathbf{M L}]}{[\mathbf{M}][\mathbf{L}]} \\
\mathbf{M}+2 \mathbf{L} \Leftrightarrow \mathbf{M L}_{2} & \boldsymbol{\beta}_{2}=\frac{[\mathbf{M L}]}{[\mathbf{M}][\mathbf{L}]^{2}} \\
\mathbf{M}+3 \mathbf{L} \Leftrightarrow \mathbf{M L}_{3} & \boldsymbol{\beta}_{3}=\frac{[\mathbf{M L}]}{[\mathbf{M}][\mathbf{L}]^{3}}
\end{array}
$$

The equation relating the stepwise and overall stability constants is indicated by equation: -

$$
b_{\mathbf{n}}=\mathbf{k}_{1} \mathbf{k}_{2} \ldots . . . \mathbf{k}_{\mathbf{n}}
$$

In biological systems, many factors affect metal-ligand complex formation. A hard-soft acid-base consideration is one basic factor ${ }^{76}$. Concentrations of the metal and ligand at the site of complexation are determined locally through concentration gradients, membrane permeability to metals and ligands, and other factors. Various competing equilibria - solubility products, complexation, and/or acid-base equilibrium constants-sometimes referred to as "metal ion speciation," all affect complex formation ${ }^{76}$. Ion size and charge, preferred metal coordination geometry, and ligand chlelation effects all affect metal uptake. To better measure biological metalligand interactions, an "uptake factor" is defined as $\mathrm{K}_{\mathrm{ML}}[\mathrm{M}]$, where $\mathrm{K}_{\mathrm{ML}}$ is the stability constant $\mathrm{K}_{1}$ and $[\mathrm{M}]$ is the concentration of metal ion. Great selectivity for metal species is necessary to concentrate the necessary ions at sites where they are needed. Differentiating ligands are those preferred by the cation in question ${ }^{77}$. The more stable product is the one thermodynamically controlled product.

The product is formed by lowering the activation energy ${ }^{78}$.<smiles>O=Cc1ccco1</smiles>

2-furaldehyde (F)<smiles>O=C1CCCCC1</smiles>

cyclohexanone $\mathrm{C}$<smiles>C[I+]C</smiles>
semicarbazide<smiles>NC(N)=O</smiles>
semicarbazide<smiles>NC(=O)N=Cc1ccco1</smiles>

2-furaldehyde semicarbazone (FS)<smiles>NC(=O)N=C1CCCCC1</smiles>

cyclohexanone semicarbazone

(CS)

One of the products, either FS or CS, will be the kinetically controlled product. The other product will be the thermodynamically controlled product ${ }^{78}$.

TOXIC EFFECTS OF SEMICARBAZONE AND THIOSEMICARBAZONE

Semicarbazide is a metabolite of the nitrofurane Nitrofurazone (5-nitro-2-furaldehyde semicarbazone), used as indicator to detect the use of nitrofurazone in food-producing animals. 


\section{Parent compound}<smiles>NC(=O)N/N=C/c1ccc([N+](=O)[O-])o1</smiles>

Nitrofurazone

\author{
Metabolite, \\ covalent bound to the matrix<smiles>NNC(N)=O</smiles> \\ Semicarbazide (SEM)
}

Due to their carcinogenic properties the use of nitrofurans is prohibited within the EU in animal breeding (Commission Regulation 37/2010) to harmonize the detection of semicarbazide a Minimum Required Performance Limit (MRPL) of $1 \mu \mathrm{g} / \mathrm{kg}$ is set within the EU (Commission Decision 2003/181).

\section{CONCLUSION}

This review has dealt with an extensive literature study relating semicarbazone and thiosemicarbazone and their transition metal complex. The presence of amide, imine and thione groups makes them potential polydentate ligands. The transition metal complexes are far more biologically active than uncoordinated semicarbazone and thiosemicarbazone. Many authors have reported anticancer, antibacterial, antifungal, antimalarial, antiviral and antifilarial activities of these compounds. Thiosemicarbazone metal complexes have also been investigated as radical scavengers. Schiff base metal complexes were also found to be active against yeast and also act as herbicides, insecticides, rotenticides, plant growth regulator and their usage in the treatment of diseases such as antitumor, leprosy, mental disorders and their enhanced biological activity has been an active area of investigation for the future researchers. The composition of ligand can be determined by the CHN analysis. For the characterization of these compounds, ${ }^{1} \mathrm{HNMR}$ and IR spectral studies are very important.

\section{REFERENCE}

1. Klayman L., F. Bartosevich, J. Bruce, Medicinal Chemistry. 26,431-450, (2009).

2. Shalin K, Dhar ND, Sharma NP. "Application of metal complexes of Schiff, bases" J. Sci and Indust, 64, 34 (2009).

3. Wilfredo H., Juan P. Complexes of Semicarbazone and Thiosemicarbazone, J. Chemi sci. 14, 10, (2006).

4. Shalin K, Dhar N, Sharma N. "Application of metal complexes of Schiff, bases" J. Sci . and Indust,64,34,(2009).

5. Pal I., Basuli F., and Bhattacharya S. "Thiosemicarbazone complexes of the platinum metals. A story of variable coordination modes," Proceedings of the Indian Academy of Sciences: Chemical Sciences, 60, 20, (2012).

6. Tenório et al. Antifungal properties of metal thiosemicarbazone, med.sci, 40, 24, (2015).

7. Banerjee et al., antiviral activities of thiosemicarbazone, med.sci, 36,20, (2011)

8. Wilfredo H., Juan P. Complexes of Semicarbazone and Thiosemicarbazone, J. Chemi sci. 14, 10, (2006).

9. Basuli F., Peng S., Bhattacharya S., Inorg. Chem. 40, 1126, (2001).

10. Farrell, N. Coord. Chem. Rev., 232, 1, (2002).

11. West D.; Padhye S.; Sonawane P. In Structure and Bonding, Springer-Verlag: New York, 76, 1-49 (1991).

12. Kirchgessner M., Schnegg A. Nutr. Metab. 1979; 23: 62-64

13. Kasuga N., Sekino K, Kuomo C, Shimada,M. Ishikawa and. Nomiya K, Synthesis, struc tural characterization and antimicrobial activities of 4- and 6-coordinate nickel (II) complexes with three thiosemicarbazones and semicarbazone ligands, J. Inorg. Biochem. 84, 55, (2001).

14. Sharma R, Agarwal S. Rawat, M. Nagar, Synthesis, Characterization and Antibacterial Activity of Some Transition Metal cis 3,7-dimet-hyl-2,6 octadiensemicarbazone Complexes, Trans. Met. Chem. 31, 201, (2006).

15. Lindskog S. Structure and Mechanism of Carbonic Anhydrase. Pharmacology and Therepeutics 74: 1-20, (1997)

16. McCarthy T., Zeelie J., Krause D. The antimicrobial action of zinc ion/antioxidant combinations. Clinical Pharmacology \& Therapeutics 17: 51-54, (1992).

17. Simmer K, Thompson R. Zinc in the fetus and newborn. Acta Paediatr Scand Suppl 319: 158-163, (2012).

18. Zundahl S. Chemical Principles. ${ }^{\text {rd }}$ edition, Houghton Mifflin Co., New York. 710-711, 1019-1020, (2013).

19. Dowling C. and Perkin G., Polyhedron 15, 2463, (2006).

20. Sorenson J and Siegel H., In: Metal ions in biological system. New York - Basel, Dekker M., Inc. 78, (2016)

21. Gong P., Stewart D., Ellerbe M., Figueroa G., Beckman, S. J. Biol. Chem. 276, (2011).

22. Wedepohl K., "The composition of the continental crust," Geochimica et Cosmochimica Acta, vol. 59, no. 7, pp. 1217-1232, (2015).

23. Nordberg G., Nogawa K. "Cadmium," in Chapter 23 in Handbook of the Toxicology of Metals. 445-486, 
(2007).

24. Edelson M., Sci. Am. 68, 259, (2017).

25. Baden H. The Chemotherapy of Psoriasis; Ed.; Pergamon: New York, (2004).

26. Chen D., Cui Q., Yang H.and Q. Dou, Cancer Res. 66, 10425, (2006).

27. Renade S. and Panday V., Sci. Total Environ., 40, 245. (1984)

28. Singh K, Barwa M., Tyagi P, Eur. J. Med. Chem.,42, 394, (2008).

29. Reddy K., and Babu P., Synthesis, spectral studies and nuclease activity of mixed ligand copper (II) complexes of hetero aromatic semicarbazones/thiosemicarbazones and pyridine, J. Inorg. Biochem. 77,169, (1999).

30. Klaassen C., Casarett and Doull's Toxicology the Basic Science of Poisoning, sixth ed. McGraw-Hill, Medical Publishing Division, New York, 839, (2016).

31. JiangY. and Zheng W.: Cardiovascular toxicities Upon Manganese Exposure. Cardiovascular toxicology, 5(4), 345-354, (2005).

32. Table E. and Table V.: Dietary reference intakes for vitamin A, vitamin K, arsenic, boron, chromium, copper, iodine, iron, manganese, molybdenum, nickel, silicon, vanadium, and zinc (2011).

33. Greger J.: Dietary standards for manganese: overlap between nutritional and toxicological studies. The Journal of nutrition, 128(2), 368S-371S (2012).

34. Lönnerdal B., Keen C. L. and Hurley L. S.: Manganese binding proteins in human and cow's milk. The American Journal of Clinical Nutrition, 41(3), 550-9 (1985).

35. Couper J.: On the effects of black oxide manganese when inhaled into the lungs. British annals of medicine, pharmacy, vital statistics and general science, 1, 41-42, (2006).

36. Encyclopedia of Reagents for Organic Synthesis, (2001).

37. Kolb V., Stupar J., Janota T., Duax W., J. Og. Chem. 54, 2341, (2009).

38. Encyclopedia of Reagents for Organic Synthesis, (2001).

39. Kolb V., Stupar J., Janota T., Duax W. Chem. 54, 2341,(20014).

40. IUPAC, Compendium of Chemical Terminology, 2nd ed. (the "Gold Book") (2005). Online corrected version: (2006) "Schiff base".

41. IUPAC, Compendium of Chemical Terminology, 2nd ed. (the "Gold Book") (1997). Online corrected version: (2006) "azomethines".

42. Shahu R, Thakur DS, Kashyap P Schiff base: An overview of its medicinal chemistry potential for new drug molecule. Int J Pharm Sci Nanotech 5: 1757-1764, (2012).

43. Wiley J. \& Sons, Bioinorganic Chemistry: A Short Course, (2002).

44. Wiley J. \& Sons, Bioinorganic Chemistry: A Short Course, (2009).

45. Shalin K, Dhar ND, Sharma NP "Application of metal complexes of Schiff, bases" J. Sci . and Indust. Res.: 68: 181-187, (2009).

46. Basuli F., Peng S.M., Bhattacharya S., Inorg. Chem. 40, 1126, (2001).

47. Sreekanth A, Kala U, Nayar C. Polyhedron 23 (41), (2008).

48. Wiley J. \& Sons, Bioinorganic Chemistry: A Short Course, (2004).

49. Jayanthi1 K., Meena1 P., Chithra1 K., Kannan1 S., Synthesis And Microbial Evaluation of Copper(II) Complexes of Schiff Base Ligand, (2017).

50. Leovac L., the Wide Pharmacological Versatility of Semicarbazones, Thiosemicarbazones and Their Metal Complexes, (2014).

51. Marina A. The antimicrobial activity of lapachol and its semicarbazole derivatives, 46, 20, (2013).

52. Marina A. The antimicrobial activity of lapachol and its semicarbazole derivatives, 26, 24, (2012).

53. wilferdo H., Cytotoxic activities of benzaldehyde thiosemicarbazone derivaties, 40,20, (2008).

54. Jayanthi K., Meena R. Microbial evaluation of copper (II) complexes. Chemical and bioscience,4,3, (2017).

55. Meena R.P. Microbial evaluation of copper (II) complexes. Chemical and bioscience, 8,4,(2015).

56. El-Shazly R. M. Al-Hazmi G. A., "Synthesis and spectroscopic characterization of cobalt (II) thiosemicarbazone complexes," Journal of Coordination Chemistry, pp. 845-859, (2006).

57. Farrell, N. Coord. Chem. Rev., (2012).

58. Kelayman D., Bartosevich J. Biological activities of semicarbazone derivatives, 46, 6, (2016).

59. Bermejo E., Carballo R. Biological activities of thiosemicarbazone, 10, 6, (2012).

60. Laxmi S. and Rajitha B. Synthesis and antimicrobial activity of newer indole semicarbazones. Med. Chem. Res.: 85-90, 21, (2012).

61. Jafri L, Ansari F, Jamil M, Kalsoom S, Qureishi S and Mirza B. Microwave-assisted synthesis and bioevaluation of some semicarbazones. Chem. Biol. Drug Des. 79: 950-959, (2012).

62. Neelam B., Kakalu H. Synthesis and in vitro antiprotozoa activity of semicarbazone derivatives. Bioinorganic and medicinal chemistry, 16,4,(2012).

63. Cerecetto H. González, M., Curr. Topics Med. Chem., (2002).

64. Dobek A.S.; Klayman D.; Dickson J., Scovill J.; Tramont E. Antimicrob. Agents Chemother., 18, 27, (2009). 
65. Dobek A.S.; Klayman D.L.; Dickson Jr., E.T.; Scovill J.P.; Tramont E.C. Antimicrob. Agents Chemother.,28, 26,(1990).

66. Kovala-Demertzi, D.; Demertzis, M.A.; Miller, J.R.; Papadopoulou, C.; Dodorou, C.; Filousis, G. J. Inorg. Biochem.,86(2-3), 555, (2011).

67. Klayman, D.; Scovill, J.; Lambros, A. Pharm. Sci.,73, 1763, (2014).

68. Dobek, A.; Klayman, D.; Scovill, J.; Dickson, J. Chemotherapy,32, 25,(1986).

69. Kasuga, N.; Sekino, K.; Koumo, C.; Shimada, N.; Ishikawa, M.; Nomiya, K. J. Inorg. Biohem., 84, 55, (2000).

70. Fahmi, N.; Singh, R. J. Indian Chem. Soc., 73, 257, (2006).

71. Singh, D.; Singh, R.V. J. Inorg. Biochem. 15, 227, (1999).

72. Maiti, A.; Guha, A.; Ghosh, S. Inorg. Biochem., 33, 57(2008).

73. Singh, S.; Pandeya, S. Boll. Chim. Farm.,140(4), 238, (2001).

74. Kolocouris, A.; Dimas, K.; Pannecouque, C. Bioorg. Med. Chem. Letters, (2002).

75. Offiong, O.E.; Etok, C.; Martelli, S. Il Farmaco, 51, 801, (2008).

76. Sadler, P. Adv. Inorg. Chem. stability constants of semicarbazone metal complex, 8, 4, (2011).

77. Kaur H. and Singla A. Comparative study of stability constants and thermodynamic properties of complexation, 8, 6, (2007).

78. Olagboye S., Okoronkwo A. and Lajide L. Stability constant and thermodynamic studies of metal complexes with Benzimidazole, 40, 6, (2014). 